\title{
Knowledge, Attitudes, and Barriers Regarding Health Research among Medical Students in Saudi Arabia
}

\author{
Mubashir Zafar ${ }^{1 *}$, Abdul Kareem², Ali Fawaz ${ }^{2}$, Reem Fares ${ }^{2}$, Wadha Saad ${ }^{2}$ \\ ${ }^{1}$ Department of Family and Community Medicine, College of Medicine, University of Hail, Hail, Kingdom of Saudi Arabia; ${ }^{2}$ Department \\ of Public Health, College of Public Health, Imamm Abdul Rehman Bin Faisal University, Dammam, Kingdom of Saudi Arabia
}

\begin{abstract}
AIM: The objective of the study is to determine the knowledge, attitude, and barriers regarding health research among health science students.

METHODS: It is a cross-sectional study and 294 study participants were selected through stratified random sampling from different health science colleges (medicine, dental, nursing, and applied science). A validated, structured, and pre-tested questionnaire was used. Knowledge and attitudes were determined through scales. Analysis of variance and t-test were applied to determine the mean scores of knowledge and attitude, and multiple regression analysis was used to determine the factors which affect on knowledge and attitude.

RESULTS: Knowledge and attitude mean scores were $4.36 \pm 2.44$ and $2.74 \pm 1.17$, respectively. Knowledge and attitude were increase significantly with increasing academic year of study in all health science colleges (Regression coefficient $0.043[p=0.032]$ and $0.005[p=0.040]$ for knowledge and attitudes, respectively). Most common barriers for research were lack of proper mentoring from the faculty staff and lack of time due to over burden with educational activities

CONCLUSION: Health science students had moderate level of knowledge and attitude toward health research with common barrier which was lack of proper mentoring from the faculty. There is need for address the barrier for research and more integration of curriculum with research which improved the knowledge and attitude level.
\end{abstract}

Edited by: Slavica Hristomanova-Mitkovska Citation: Zafar M, Kareem A, Fawaz A, Fares R, Saad W. Knowledge, Attitudes, and Barriers Regarding Health Research among Medical Students in Saudi Arabia. Open Access Maced J Med Sci. 2021 Apr 22; 9(E):302-306 https://doi.org/10.3889/oamjms.2021.588 Keywords: Attitude; Barrier; Health; Knowledge; Students *Correspondence: Dr. Mubashir Zafar, Department of . Received: 14-Feb-2021 Revised: 09-Apr-202 Accepted: 12-Apr-202

Copyright: ๑ 2021 Mubashir Zafar, Abdul Kareem Ali Fawaz, Reem Fares, Wadha Saad Funding: This research did not receive any financial support. Competing Interest: The authors have declared that no Open Access: This is an oting interest exists. tributed under the terms of the Creative Commons Attribution-NonCommercial 4.0 International License (CC BY-NC 4.0)

\section{Introduction}

Research is the basic component in the curriculum health science education [1]. There are two basic skills required for research which are reasoning skills and critical thinking skills. These skills develop positive attitude toward scientific research [2]. There are different studies proved that research skill is strongly associated with postgraduate research activities and research project in professional life of students [3], [4]. The most of health science professionals were lack of research skills and there is a need of competent health professionals who have strong research skills.

The undergraduate students have a potential to learn the basic research skills, therefore, there is a need for developing the curriculum in which research components should be high priority. Motivating students were involved in research activities and acquire the research skill which will helpful in their professional life. This workforce helps in countries to achieve the self-dependence in research and science [5], [6].
There are innovative trends in science education which focus on acquiring the knowledge, attitude, and skills toward research which is also called as evidence-based learning [7]. Different creative methods of learning have adopted which help the students for self-directed learning skills which is lifelong competency developed in the students. The most common learning approach is problem-based learning (PBL), which is good learning strategy among science institutions throughout the world. It is helpful the students to improve the critical thinking ability which is used in research [8].

There is different level of research components in health science curriculum in different countries. The primary objective of study is to determine the knowledge, attitude, and barriers related to participation of research among undergraduate health science in Kingdom of Saudi Arabia. This is the indicators of student's awareness and recognition of innovative knowledge getting capacity to impact health science. The secondary objective of this study was to identify the factors such as gender, age, and year of study at university which are associated with student's knowledge and attitude toward scientific research. 


\section{Methods}

\section{Study setting, study participants, and study design}

In university, there are 4-year program in different health science (bachelor of medicine; bachelor of dental surgery, bachelor of nursing, and bachelor of applied sciences). All $1^{\text {st }}, 2^{\text {nd }}, 3^{\text {rd }}$, and $4^{\text {th }}$ years students of different colleges were included. It is a cross-sectional study.

\section{Sampling technique and sample size}

The participants were selected through stratified random sampling. The participants of study were randomly selected according to the proportion of students in the classes. Sample size was calculated from the World Health Organization health studies software, $5 \%$ margin of error with $95 \%$ confidence interval and assuming $25.7 \%$ prevalence of good knowledge from the previous study [7], $5 \%$ bond-on error, the required sample size is 294 .

\section{Data collection procedure}

After getting permission from dean of colleges, the questionnaires were distributed among study participants with written consent form. Study participants were requested to return from within a week.

\section{Questionnaire}

A validated and structured questionnaire was used [8]. The questionnaire was pretested and find out any inconsistency of responses and modification of questionnaire according to response from study participants and build a final version of questionnaire.

The questionnaire has four parts; the first part is comprised sociodemographic characteristic of study participants, the second part is student's knowledge, the third part is attitudes toward research, and the fourth part is barrier to research. Demographic section included age, gender, type of high school course, year of study and mode of learning at medical school (PBL vs. lecture-based learning [LBL]), and place of origin. Learning style classifies into traditional LBL and PBL.

The second section is knowledge which comprised 10 questions. Right answers as percentage were calculated as a of knowledge score and third section attitude which comprised of Six questions and right answer were scored on a scale of 0.0 (unfavorable attitude) to 1.0 (favorable attitude) and each individual score of individual questions was summed and then transformed into proportion to characterize the attitude score and the fourth section which is comprised of 10 questions of barrier to research section.

\section{Statistical analysis}

EpiData software was used for data entry. Data were entered into Statistical Package for the Social Sciences version 24 (SPSS, Inc., Chicago, IL, USA). Descriptive statistical analysis was calculated for mean scores and proportions. Inferential statistical analysis was used by multiple linear regression models which were used to test association of age and year of study with the knowledge and attitude. Analysis of variance and t-test were used to look for similar putative associations of type of high school, mode of study, and gender. $p<0.05$ was considered as statistical significance. Multiple linear regressions were applied to determine the predictors which affect the knowledge and attitude toward research.

\section{Results}

Mean age of participants was $21.53 \pm 1.05$ years. Most $(52.8 \%)$ of the study participants were male, $60.2 \%$ of students were scored good grade point average, and $64.6 \%$ of students were learned from LBL (Table 1).

Table 1: Sociodemographic characteristics of study participants $(n=294)$

\begin{tabular}{|c|c|}
\hline Characteristics & Frequency (\%) \\
\hline Age (years) (Mean $\pm \mathrm{SD})$ & $21.53 \pm 1.05$ \\
\hline \multicolumn{2}{|l|}{ Gender } \\
\hline Male & $155(52.8)$ \\
\hline Female & $139(47.3)$ \\
\hline \multicolumn{2}{|l|}{ Marital status } \\
\hline Single & $48(16.3)$ \\
\hline Married & $246(83.7)$ \\
\hline \multicolumn{2}{|l|}{ Colleges } \\
\hline Medicine & $101(34.3)$ \\
\hline Dental & $98(33.3)$ \\
\hline Nursing & $65(22.1)$ \\
\hline Applied medical science & $30(10.2)$ \\
\hline \multicolumn{2}{|l|}{ Academic year of study } \\
\hline $1^{\text {st }}$ year & $34(11.6)$ \\
\hline $2^{\text {nd }}$ year & $196(66.7)$ \\
\hline $3^{\text {rd }}$ year & $62(21.1)$ \\
\hline $4^{\text {th }}$ year & $2(0.7)$ \\
\hline \multicolumn{2}{|c|}{ Academic score (grade point average $)^{*}$ (last semester) } \\
\hline Average & $117(39.8)$ \\
\hline Good & $177(60.2)$ \\
\hline \multicolumn{2}{|l|}{ Mode of learning } \\
\hline Problem based & $104(35.4)$ \\
\hline Lecture based & $190(64.6)$ \\
\hline
\end{tabular}

Females scored better on knowledge scale, college of medicine students were better score on knowledge and attitude scale, and this difference was statistically significant. Academic year and academic scores were not a significant predictor of knowledge or attitude about research. PBL was associated with a better score on both knowledge and attitude scales (Table 2).

Age was not a statistically significant factor in determining scores on knowledge scales. After adjusting of covariate, the academic year was the significant predictor on both knowledge and attitude scores. Increase in duration of study by 1 year increased the knowledge score by $0.04 \%$ with a correlation coefficient $(r)$ of 0.058 $(p=0.001)$. Similarly, increase in duration of study by 1 
year was increased the attitude score by $0.05 \%$ with a correlation coefficient $(r)$ of $0.012(p=0.042)$, (Table 3).

Table 2: Knowledge and attitude toward research according to gender, colleges, mode of learning, academic year, and academic score at medical school $(n=294)$

\begin{tabular}{lll}
\hline Characteristics & $\begin{array}{l}\text { Knowledge Mean } \pm \text { SD } \\
(p \text {-value })\end{array}$ & $\begin{array}{l}\text { Attitude Mean } \pm \text { SD } \\
(\mathrm{p} \text {-value })\end{array}$ \\
\hline Gender & $4.05 \pm 2.48$ & $9.67 \pm 2.32$ \\
$\quad$ Male & $4.71 \pm 2.34(0.022)$ & $9.52 \pm 1.93(0.021)$ \\
$\quad$ Female & $5.22 \pm 2.39$ & $10.23 \pm 2.19$ \\
Colleges & $4.28 \pm 2.49$ & $9.71 \pm 2.34$ \\
$\quad$ Medicine & $3.30 \pm 2.21$ & $8.81 \pm 2.41$ \\
$\quad$ Dental & $4.03 \pm 1.88(0.033)$ & $9.82 \pm 1.81(0.005)$ \\
$\quad$ Nursing & & $9.76 \pm 2.00$ \\
$\quad$ Applied medical science & $4.58 \pm 2.60$ & $9.51 \pm 2.22(0.043)$ \\
Mode of Learning & $4.24 \pm 2.34(0.058)$ & \\
$\quad$ Problem based & $3.79 \pm 1.96$ & $10.00 \pm 2.01$ \\
Lecture based & $4.41 \pm 2.54$ & $9.47 \pm 2.08$ \\
Year at College & $4.59 \pm 2.32$ & $9.82 \pm 2.43$ \\
$1^{\text {st }}$ & $5.21 \pm 1.65(0.223)$ & $8.50 \pm 0.70(0.397)$ \\
$2^{\text {nd }}$ & & \\
$3^{\text {rd }}$ & $4.44 \pm 2.42$ & $9.74 \pm 2.14$ \\
$4^{\text {th }}$ & $4.24 \pm 2.47(0.496)$ & $9.39 \pm 2.15(0.865)$ \\
Academic score & & \\
Average & & \\
$\quad$ Good & &
\end{tabular}

The proportion of each question of knowledge section was determined through descriptive statistics (Table 4).

Table 3: Predictors of score on the knowledge and attitude scales among Saudi health science students

\begin{tabular}{lll}
\hline Predictors & $\begin{array}{l}\text { Regression } \\
\text { coefficient }(b)(p \text { values) }\end{array}$ & $\begin{array}{l}\text { Correlation } \\
\text { coefficient }(r) \text { ( } p \text { values) }\end{array}$ \\
\hline $\begin{array}{l}\text { Knowledge } \\
\text { Academic year }\end{array}$ & $0.043(0.032)$ & \\
$\quad$ Age & $0.024(0.741)$ & $0.058(0.001)$ \\
Attitude & & $0.051(0.611)$ \\
$\quad$ Academic year & $0.005(0.040)$ & $0.012(0.042)$ \\
Age & $-0.055(0.716)$ & $-0.024(0.340)$ \\
\hline
\end{tabular}

Table 4: Proportion of health science students with correct answers for questions of knowledge

\begin{tabular}{|c|c|c|}
\hline Questions & Frequency (n) & Proportion (\%) \\
\hline $\begin{array}{l}\text { 1. How would you define the scientific } \\
\text { hypothesis? } \\
\text { An answer or solution to a question which } \\
\text { has a capacity of verification or empirical } \\
\text { demonstration* }\end{array}$ & 135 & 45.9 \\
\hline $\begin{array}{l}\text { 2. How would you define scientific theory? } \\
\text { System of hypotheses logically connected to } \\
\text { one another, with common background, some } \\
\text { of which have been verified* }\end{array}$ & 116 & 39.5 \\
\hline $\begin{array}{l}\text { 3. How would you define the scientific truth? } \\
\text { Consensus of competent experts * }\end{array}$ & 39 & 13.3 \\
\hline $\begin{array}{l}\text { 4. The essential characteristic of science is: } \\
\text { All scientific conclusions are temporary* }\end{array}$ & 140 & 47.6 \\
\hline $\begin{array}{l}\text { 5. A scale from } 1 \text { to } 5 \text { (like grades on an } \\
\text { examination) is called Ordinal * }\end{array}$ & 166 & 56.5 \\
\hline $\begin{array}{l}\text { 6. Representativeness is a key characteristic of } \\
\text { a Sample* }\end{array}$ & 167 & 56.8 \\
\hline $\begin{array}{l}\text { 7. MEDLINE is: } \\
\text { Medical database* }\end{array}$ & 82 & 27.9 \\
\hline $\begin{array}{l}\text { 8. In the previous year, you have published a } \\
\text { paper in a prestigious Journal of Immunology. } \\
\text { Now you want to check the number of } \\
\text { citations your paper has received. The best } \\
\text { way to do it would be to search the: } \\
\text { Citation index of the Science Citation Index } \\
\text { database* }\end{array}$ & 162 & 55.1 \\
\hline $\begin{array}{l}\text { 9. The part of a scientific paper is: } \\
\text { Acknowledgment to persons who assisted } \\
\text { you during the research* }\end{array}$ & 134 & 45.6 \\
\hline $\begin{array}{l}\text { 10. All listed rules apply to the process of writing } \\
\text { an introduction section of a scientific paper } \\
\text { except: } \\
\text { d. Make it longer rather than shorter* }\end{array}$ & 143 & 48.6 \\
\hline Mean score $( \pm$ SD) & $4.36 \pm 2.44$ & \\
\hline
\end{tabular}

Out of 294 students, $75.5 \%$ were think that undergraduate students should participate in research and $62.9 \%$ were belief that undergraduate students can plan and conduct a research project and write a scientific paper (Table 5).

Table 5: Responses to questions determining attitudes of health science students toward scientific research

\begin{tabular}{llll}
\hline Statement & Yes & No & Undecided \\
\hline $\begin{array}{l}\text { 1. Do you feel confident in interpreting and } \\
\text { writing a research paper? }\end{array}$ & $158(53.6)$ & $54(18.4)$ & $82(27.9)$ \\
$\begin{array}{l}\text { 2. Have you ever participated in a research } \\
\text { project (apart from mandatory academic }\end{array}$ & $138(46.9)$ & $131(44.6)$ & $25(8.5)$ \\
$\quad$ projects)? & & & \\
$\begin{array}{l}\text { 3. Have you ever written a scientific paper? } \\
\text { 4. Do you think undergraduate students } \\
\text { should participate in research? }\end{array}$ & $133(45.2)$ & $122(41.5)$ & $39(13.3)$ \\
$\begin{array}{l}\text { 5. Do you think undergraduate students can } \\
\text { plan and conduct a research project and }\end{array}$ & $185(62.9)$ & $72(24.5)$ & $37(12.6)$ \\
$\quad$ write a scientific paper? & & & \\
$\begin{array}{l}\text { 6. Medical students can plan and conduct } \\
\text { research project without supervision }\end{array}$ & $105(35.7)$ & $157(53.4)$ & $32(10.9)$ \\
\hline Mean score ( \pm SD) & $2.74 \pm 1.17$ & & \\
\end{tabular}

The most $(74.1 \%$ and $71.4 \%)$ common barriers for health research were lack of time due to over burden with educational activities including examination and lack of proper mentoring from the faculty staff (Table 6).

Table 6: Perceived barriers toward participation in scientific research as stated by the included medical students

\begin{tabular}{ll}
\hline Perceived barriers & Frequency $\mathrm{n}(\%)$ \\
\hline $\begin{array}{l}\text { Lack of proper mentoring from the faculty staff. } \\
\text { Our faculties do not give the opportunity to conduct our own } \\
\text { research }\end{array}$ & $210(71.4)$ \\
$\begin{array}{l}\text { Lack of time due over burden with educational activities } \\
\text { including examinations. }\end{array}$ & $218(74.6)$ \\
$\begin{array}{l}\text { Lack of proper laboratory and other facilities } \\
\text { Inefficient faculty staff to deliver necessary knowledge and }\end{array}$ & $171(58.2)$ \\
skills & $168(57.1)$ \\
Inaccessibility to the medical and other electronically relevant & $143(48.6)$ \\
data bases & \\
Lack of rewarding and/or motivation & $175(59.5)$ \\
Lack of proper funding and monetary problems. & $180(61.2)$ \\
Lack of appropriate knowledge and necessary skills. & $192(65.3)$ \\
Lack of interest & $168(57.1)$ \\
\hline
\end{tabular}

\section{Discussion}

The present study found that health sciences students had moderate level of knowledge and attitude toward health research (mean score of knowledge 4.36 out of 10 and mean score of attitude 2.74 out of 6 , respectively). Result of this study is consistent with the other study results which were conducted on Croatian medical students [8]. Our study results showed that men score of knowledge was 4.36 and Croatian student's knowledge score had 4.43 but attitude score was 6.0 which was higher to our study attitude mean score (2.74). However, only $53 \%$ of health sciences students felt confident in interpreting and writing a research paper and only $35.7 \%$ claimed the ability to do research without any supervision.

Health science student's knowledge and attitude regarding health research enhanced with increasing years of academic at college. This means that curriculum of health sciences colleges has well developed in developing research skills and structured training program. Health science students are taught basic research methodology which includes statistics, 
epidemiology during the semester. Health science students are taught basic research methodology which includes statistics, epidemiology during the semester and in higher academic year extensive research projects which was based on community visits. In these projects, students were involved in data collection, data analysis, writing research report, and present the results of their projects. After that, it is a mandatory to publish the research in the high indexed journals. This activity of students was helped to developed research skills and good knowledge and attitude regarding health research [9].

The previous study found that attitude and knowledge level were significantly improved by increasing year of academics [10]. Another study found that students at the $2^{\text {nd }}$ year of academics had the highest level of knowledge and attitude compared to previous year of academics [4].

Gender was the significant predictor regarding knowledge and attitude level among health science students. Females had significantly higher mean score of knowledge and attitude. This results contrast with other study which found that gender was not significant predictor [10]. The reasons for females were more knowledgeable due to higher numbers of female's enrolment in the colleges.

Medical college students were significant higher knowledge and attitude score compared to other colleges students. The reason for this result was because curriculum of college of medicine was more research oriented compared to other college's curriculum. This result was consistent with other study results [11], [12].

This study results found that knowledge and attitude scores were significant difference between LBL and PBL students. Year of academics variable is the confounder of knowledge and attitude score because the higher study commonly used PBL. Other studies have found that there were no differences of knowledge and attitude score between modes of learning of students [13].

The study results found that several factors called as barriers for student's participation in research. The important factors identified as barriers were lack of training, no incentive, lack of supervision, and skills. The previous study [14] showed that participate in the workshops on research methodology had good impact on students attitude toward research. Other study shown that students were involved in intercalated research projects feels that it was worthless knowledge of various issues such as interfering with social activities and social interactions [15].

Participation of students in health research was average (45.2) in the study results. The reason for this result was due to low motivation of students toward research. The results are similar to other study results which found that few students were published paper in scientific journal [16].

There are several limitations for this study, first, this is the cross-sectional study which cannot determine the temporality of outcome and independent variables. Second, there are a significant difference of curriculums between colleges, we cannot determine the factor in this study. Third, others factors not evaluated which affect the knowledge and attitude toward research such factors were funding opportunity, research infrastructure, and cost of education.

\section{Conclusion}

Knowledge and attitude toward research were average among health science students. There are several factors which associated with barriers from participation in health research. There is a need for further research to explore factors associated with barriers to participation in health research. Furthermore, its need to revise the curriculum which should be robust in health research which demands of the community.

\section{Authors' Contributions}

$\mathrm{MZ}$ and $\mathrm{AK}$ conceived and designed the study. AK, AF, RF, and WS administered questionnaires. AK, $A F$, and $M Z$ managed analyzed and interpreted data. $\mathrm{MZ}$ prepared the manuscript. All authors approved the final manuscript.

\section{References}

1. Scaria V. Whisking research into medical curriculum: The need to integrate research in undergraduate medical education to meet the future challenges. Calicut Med J. 2004;2:e1.

2. Aslam F, Shakir M, Qayyum MA. Why medical students are crucial to the future of research in South Asia. PLoS Med. 2005;2:e322. https://doi.org/10.1371/journal.pmed.0020322 PMid:16288553

3. Reinders JJ, Kropmans TJ, Cohen-Schotanus J. Extracurricular research experience of medical students and their scientific output after graduation. Med Educ. 2005;39:237. https://doi. org/10.1111/j.1365-2929.2004.02078.x

PMid:15679693

4. Hren D, Lukić IK, Marušić A, Vodopivec I, Vujaklija A, Hrabak $M$, et al. Teaching research methodology in medical schools: Students' attitudes towards and knowledge about science. Med Educ. 2004;38(1):81-6. https://doi. org/10.1111/j.1365-2923.2004.01735.x

PMid:14962029 
5. Wyngaarden J. The Clinical Investigator as endangered species. N Eng J Med. 1979;301(23):1254-9.

PMid:503128

6. Pasko T, Smart D. Physician Characteristics and Distribution in the US. Chicago, Illinois: American Medical Association Press; 2004.

7. The PLoS Medicine. Improving health by investing in medical education. PLoS Med. 2005;2:e424. PMid: 16363918

8. Vodopivec I, Vujaklija A, Hrabak M, Lukiæ IK, Marušiæ A, Marušiæ M. Knowledge about and attitudes towards science of first year medical students. Croat Med J. 2002;43:58-62 PMid:11828562

9. Segal $S$, Lloyd $T$, Houts $P S$, Stillman PL, Jungas RL, Greer RB. The association between students' research involvement in medical school and their postgraduate medical activities. Acad Med. 1990;65(8):530-3. https://doi. org/10.1097/00001888-199008000-00010

\section{PMid:2383337}

10. Khan H, Khawaja MR, Rauf MA, Fatmi Z. Knowledge and attitudes about health research amongst a group of Pakistani medical students. BMC Med Educ. 2006;6:54. https://doi. org/10.1186/1472-6920-6-54 PMid:17081286

11. Page J, Hellen RF, Kinlay S, Lim LL, Qian W, Suping Z, et al. Attitudes of developing world physicians to where medical research is performed and reported. BMC Public Health.
2003;3:6. https://doi.org/10.1186/1471-2458-3-6

PMid:12529182

12. Aslam F, Qayyum MA, Mahmud H, Qasim R, Haque IU Attitudes and practices of postgraduate medical trainees towards research a snapshot from Faisalabad. J Pak Med Assoc. 2004;54(10):534-6.

PMid: 15552293

13. Sanson-Fisher RW, Lynagh MC. Problem-based learning: A dissemination success story? Med J Aust. 2005;183:258-60. https://doi.org/10.5694/j.1326-5377.2005.tb07032.x

PMid:16138801

14. Vujaklija A, Hren D, Sambunjak D, Vodopivec I, Ivanis A, Marusić A, et al. Can teaching research methodology influence students' attitude toward science? Cohort study and nonrandomized trial in a single medical school. $J$ Investig Med. 2010;58(2):282-6. https://doi.org/10.2310/ jim.0b013e3181cb42d9

PMid:20130460

15. Park SJ, Liang MM, Sherwin TT, McGhee CN. Completing an intercalated research degree during medical undergraduate training: Barriers, benefits and postgraduate career profiles. N Z Med J. 2010;123(1323):24-33.

PMid:20930907

16. Aslam F, Waheed A. An audit of the students' corner of Journal of the Pakistan Medical Association. J Pak Med Assoc 2005;55(11):517-9.

PMid:16304879 